Stabilitas Fisik dan Pengukuran Nilai Sun Protection Factor Sediaan Tabir Surya pada Kondisi Stress Penyimpanan dengan Spektrofotometri

\title{
Physical Stability and Sun Protection Factors Measurement of Sunscreen Preparations in Stress Storage Conditions Using Spectrophotometry
}

Widi Wulandari,
Hendri Wasito*,
Sri Sutji Susilowati
Jurusan Farmasi,
Universitas Jenderal
Soedirman.
Jalan Dr. Soeparno,
Karangwangkal,
Purwokerto
Alamat email
korespondensi :
hendri.apt@gmail.com
Kata kunci: tabir
surya, stabilitas
sediaan,
spektrofotometri,
sediaan farmasi

Keywords: sunscreen, preparation stability, spectrophotometry, pharmaceutical dosage form

\begin{abstract}
Abstrak
Sediaan tabir surya dapat digunakan untuk menyerap sinar matahari secara efektif terutama pada daerah emisi gelombang UV. Kondisi stress saat penyimpanan suatu sediaan dapat mempengaruhi sifat fisik dan kimiawi. Penelitian ini bertujuan untuk menentukan pengaruh kondisi stress penyimpanan terhadap stabilitas fisik dan nilai Sun Protection Factor (SPF) sebagai efektivitas dari sediaan tabir surya yang disimpan dalam tiga suhu berbeda.

Penelitian eksperimental ini dilakukan dengan pemilihan sampel tabir surya dan pengujian stabilitas fisik meliputi pengamatan warna, pengamatan fisik, uji pH, uji daya sebar, uji daya lekat, serta pengukuran nilai SPF sediaan tabir surya lotion dan gel dengan spektrofotometri yang disimpan pada suhu ruang $\left(25^{\circ} \mathrm{C}\right)$, suhu rendah $\left(4^{\circ} \mathrm{C}\right)$, dan suhu tinggi $\left(40^{\circ} \mathrm{C}\right)$.

Kondisi stress penyimpanan mempengaruhi sifat fisik sediaan berupa daya lekat, daya sebar, dan memengaruhi secara signifikan nilai SPF sediaan $(\mathrm{p}<0,05)$ mulai hari ke-14 penyimpanan.
\end{abstract}

\footnotetext{
Abstract

Sunscreen preparations can be used effectively to absorb sunlight especially in the $U V$ wave emission region. The stress condition during storage of a preparation may affect physical and chemical properties. This study aims to determine the effect of stress storage conditions on physical stability and nilai Sun Protection Factor (SPF) values as the effectiveness of sunscreen preparations that stored in three different temperatures.

This experimental study was conducted with the selection of sunscreen samples and performing physical stability tests in termed of color observation, physical observation, $p H$ value, spreading test, adhesive test, and SPF value measurement of sunscreen using spectrophotometry in lotion and gel dosage forms stored at room temperature $\left(25^{\circ} \mathrm{C}\right)$, low temperature $(4 \circ \mathrm{C})$, and high temperature $\left(40{ }^{\circ} \mathrm{C}\right)$.

The results showed that the stress storage condition influenced the physical properties of the preparation in the form of adhesive property, spreading capacity, and significantly affect the SPF value of the sunscreen $(p<0.05)$ after 14 days of storage.
} 


\section{Pendahuluan}

Sinar matahari memiliki efek menguntungkan bagi kesehatan serta efek merugikan berupa kemampuannya dalam merusak kulit secara akut maupun kronis. Sinar matahari atau sinar ultraviolet (UV) yaitu UV-B (290-320 $\mathrm{nm})$ dan UV-A (320-400 nm) merupakan sinar yang sampai ke bumi dan dapat berpenetrasi pada kulit. Radiasi UV-B terutama bertanggung jawab pada kerusakan yang paling parah, kerusakan akut seperti terbakar sinar matahari, dan kerusakan jangka panjang termasuk kanker (Forestier, 2008).

Tabir surya merupakan senyawa yang secara fisik atau kimia dapat digunakan untuk menyerap sinar matahari secara efektif terutama pada daerah emisi gelombang UV. Sehingga penggunaan tabir surya dapat membantu mencegah gangguan pada kulit akibat paparan langsung sinar UV (Soeratri et al., 1993). Bentuk sediaan tabir surya dapat berupa salep, krim, gel, lotion, semprotan, dan wax stick (Fields, 2008). Zat yang umum digunakan sebagai tabir surya terbagi menjadi dua yaitu tabir surya fisik yang bekerja dengan melindungi kulit dengan cara memantulkan radiasi dan tabir surya kimia yang bekerja dengan cara menyerap radiasi (Shaath, 2005). Food and Drug Administration (FDA) mensyaratkan bahwa semua jenis tabir surya seharusnya memiliki kemasan yang mencantumkan indikator Sun Protection Factor (SPF) (Fields, 2008). SPF merupakan suatu nilai efektivitas dari suatu sediaan tabir surya (Bendova et al., 2007).

Kondisi stress penyimpanan merupakan kondisi suhu yang ekstrim (seperti suhu $50^{\circ} \mathrm{C}, \quad 60^{\circ} \mathrm{C}$ ) dan kelembaban yang esktrim sebesar 75\% atau lebih (ICH, 2003). Kondisi stress dapat memprediksi seberapa baik suatu produk tahan terhadap stress seperti suhu ekstrim dan cahaya (Hermann, 2004). Suhu tinggi yang diberikan pada kondisi stress dalam penyimpanan cukup untuk membuat produk berada pada kondisi degradasi yang dipercepat (Bajaj et al., 2012). Smaoui et al. (2013) telah melakukan evaluasi nilai SPF formulasi sediaan krim tabir surya yang diberi kondisi stress berupa suhu penyimpanan yaitu pada suhu $4^{\circ} \mathrm{C}$ dan $40^{\circ} \mathrm{C}$. Penelitian tersebut membuktikan bahwa stabilitas fisik sediaan yang baik menunjukkan kecenderungan mempertahankan nilai SPF selama masa penyimpanan. Namun, keterbatasan dari penelitian ini yaitu sampel yang diuji hanya berupa satu sediaan tabir surya dan tidak dilakukan pengujian pada beberapa bentuk sediaan tabir surya lainnya seperti lotion dan gel. Oleh karena itu, penelitian berupa pengujian untuk menentukan pengaruh kondisi stress penyimpanan terhadap stabilitas fisik dan nilai SPF sebagai efektivitas dari sediaan tabir surya pada berbagai bentuk sediaan yang disimpan dalam tiga suhu berbeda perlu untuk dilakukan.

\section{Metode Penelitian \\ Bahan dan Alat}

Bahan-bahan yang digunakan yaitu aquadest (Prima Cp, Purwokerto), etanol (Merck, Damstadt, Germany), dan sediaan tabir surya berupa lotion SPF 15, gel SPF 17, dan krim SPF 24.

Alat-alat yang digunakan dalam penelitian ini yaitu spektrofotometer UV-Vis single beam (Cecil CE 3021, United States), oven (Memmert, Germany), Viskometer Brookfield DVE, oven (Memmert, Germany, Jerman), lemari pendingin, neraca analitis, $\mathrm{pH}$ universal indicator paper (Merck, 
Damstadt, Germany), dan alat-alat gelas laboratorium.

\section{Prosedur Penelitian}

Pemilihan sampel dan uji viskositas

Sampel sediaan tabir surya yang diambil dari pasaran yaitu sebanyak 9 sampel yang terdiri dari bentuk sediaan lotion, gel, dan krim dengan masingmasing sebanyak tiga merek berbeda yang mencantumkan nilai SPF dan zat aktif tabir surya dalam kemasannya. Sampel yang dipilih adalah sampel dengan kriteria yaitu memiliki nilai SPF yang dapat terukur dengan metode spektrofotometri dan menunjukkan nilai SPF yang terukur mendekati dengan nilai SPF yang tertera pada kemasan.

Pengukuran viskositas dilakukan pada sampel yang terpilih sebelum dilakukan penyimpanan pada tiga suhu berbeda selama 28 hari dengan menggunakan viskometer. Sampel ditempatkan pada viskometer hingga spindel terendam. Viskometer dioperasikan dengan spindel 64 dengan kecepatan $20 \mathrm{rpm}$ untuk gel dan spindel 64 dengan kecepatan 3.0 untuk lotion, kemudian viskositas sampel dicatat yang terbaca dalam skala cps hingga didapatkan angka konstan (Voigt, 1994).

Uji stabilitas fisik dan pengukuran nilai SPF

Sampel ditentukan dengan menguji nilai SPF menggunakan metode spektrofotometri sebelum dilakukan penyimpanan pada tiga suhu berbeda. Sampel yang memenuhi kriteria, dikeluarkan dari kemasan primer kemudian disimpan dalam pot transparan yang ditutup rapat, kemudian disimpan pada tiga suhu berbeda yaitu $4^{\circ} \mathrm{C}$ didalam lemari pendingin, $25^{\circ} \mathrm{C}$ di dalam ruangan, dan $40^{\circ} \mathrm{C}$ didalam oven. Masa penyimpanan sampel adalah 28 hari dengan pengambilan sampel pada hari ke-1, 3, 7, 14, -21, dan 28 untuk dilakukan uji stabilitas fisik yang meliputi pengamatan warna, pengamatan pemisahan fisik, pengukuran $\mathrm{pH}$, pengujian daya sebar, dan pengujian daya lekat, serta uji stabilitas kimia dengan penentuan nilai SPF dengan spektrofotometer.

Pengamatan warna dilakukan secara visual dengan cara mengamati ada tidaknya perubahan warna pada sediaan yang disimpan dalam wadah penyimpanan. Pengamatan pemisahan fisik dilakukan secara visual pada semua sediaan dengan cara mengamati ada tidaknya pemisahan fisik. Pengukuran $\mathrm{pH}$ dilakukan dengan cara $0,5 \mathrm{~g}$ sediaan diencerkan dengan air suling hingga $5 \mathrm{ml}$ dengan menggunakan kertas $\mathrm{pH}$ universal. Pengujian daya sebar dilakukan dengan menimbang 0,2 gram sampel dan diletakkan diatas kaca bulat berskala dan ditutup dengan kaca lainnya. Setelah 1 menit diameter sampel yang menyebar diukur pada berbagai sisi, kemudain dirata-rata. Kemudian diberi beban sebesar 150 gram diatas kaca penutup dan setelah 1 menit diukur daya sebar yang dihasilkan secara vertikal, horizontal, dan diagonal (Secundinani, 2016). Pengujian daya lekat dilakukan dengan menimbang sebanyak kurang lebih 0,1 gram yang diletakkan diatas plat kaca kemudian ditutup dengan plat kaca yang lain. Selanjutnya plat kaca ditindih dengan berat $1 \mathrm{~kg}$ dan setelah 5 menit beban diambil kemudian dicatat waktu yang dibutuhkan hingga kedua plat kaca terpisah (Secundinani, 2016). Plat kaca dipasangkan pada alat uji dan diberikan beban sebesar 80 gram.

Preparasi sampel untuk pengukuran nilai SPF dilakukan berdasarkan metode menurut Deccache et al (2010). Sampel ditimbang sebanyak 0,05 gram kemudian dilarutkan dengan 5 $\mathrm{ml}$ etanol 50\% (v/v), dihomogenkan dan di tambahkan etanol $50 \%(\mathrm{v} / \mathrm{v})$ hingga $10 \mathrm{ml}$. Larutan kemudian 
disaring menggunakan kertas saring dengan $2 \mathrm{ml}$ larutan pertama dibuang. Kemudian diambil $0,4 \mathrm{ml}$ larutan selanjutnya yang telah disaring dan ditambahkan etanol $50 \%(\mathrm{v} / \mathrm{v})$ hingga $10 \mathrm{ml}$. Sehingga didapatkan konsentrasi larutan $2 \times 10^{-4} \mathrm{~g} / \mathrm{ml}$. Pengukuran nilai SPF dilakukan mengukur serapan masing-masing sampel dengan menggunakan spektrofotometer UV-Vis dengan pembacaan serapan setiap $5 \mathrm{~nm}$ pada rentang panjang gelombang 290-320 $\mathrm{nm}$, dengan menggunakan etanol sebagai blanko. Pengukuran dilakukan tiga kali replikasi pada masing-masing sampel. Nilai SPF ditentukan menggunakan persamaan Mansur et al (1986).

$$
\mathrm{SPF}=\mathrm{CF} x \operatorname{EE} \sum_{290}^{320} x \mathrm{I} x \text { Abs }
$$

Keterangan : $\mathrm{I}=$ intensitas spektrum sinar; Abs = serapan produk tabir surya; $\mathrm{CF}=$ faktor koreksi (10) dengan nilai $\mathrm{EE}$ $\mathrm{x}$ I adalah suatu nilai konstanta.

\section{Hasil dan Pembahasan}

\section{Pemilihan Sampel Tabir Surya dan Uji Viskositas}

Sampel sediaan tabir surya lotion, gel, dan krim dilakukan pengukuran nilai SPF dengan spektrofotometer. Hasil pengukuran nilai SPF (Tabel 1) yang diperoleh dari semua sampel menunjukkan bahwa hanya 4 sampel yang dapat terukur dengan metode spektrofotometri yaitu lotion dengan merek $\mathrm{P}$, gel dengan merek $\mathrm{A}$, gel dengan merek L dan krim merek Lt. Dari keempat sampel tersebut sediaan yang terpilih untuk pengujian selanjutnya yaitu lotion merek $\mathrm{P}$ dan gel merek L. Kandungan zat aktif yang tertera pada kemasan lotion merek $\mathrm{P}$ adalah oktil metoksisinamat, 4metilbenzelidin kampor, dan butil metoksibenzoilmetan. Sedangkan sediaan gel merek L mengandung etilheksil metoksisinamat, benzofenon3, dan butil metoksidibenzoilmetan.

Tabel 1. Data nilai SPF dari berbagai sampel yang diukur dengan spektrofotometer $(\mathrm{n}=3)$

\begin{tabular}{lcc}
\hline \multicolumn{1}{c}{ Sampel } & $\begin{array}{c}\text { Nilai SPF } \\
\text { kemasan }\end{array}$ & $\begin{array}{c}\text { Nilai SPF } \\
\text { terukur }\end{array}$ \\
\hline Lotion merek P & 15 & $15 \pm 4,1$ \\
Lotion merek N & 30 & - \\
Lotion merek V & 30 & - \\
Gel merek W & 30 & - \\
Gel merek L & 17 & $15 \pm 0,6$ \\
Gel merek A & 17 & $15 \pm 0,5$ \\
Krim merek Pa & 33 & - \\
Krim merek Au & 25 & - \\
Krim merek Lt & 24 & $13 \pm 1,1$ \\
\hline Keterangan
\end{tabular}

Keterangan : tanda (-) berarti nilai SPF tidak dapat ditentukan dengan spektrofotometri.

Hasil pengukuran menunjukkan bahwa tidak semua sampel memiliki nilai SPF yang dapat terukur dengan metode spektrofotometri khususnya pada sediaan tabir surya yang memiliki nilai SPF lebih dari 20. Hal ini sesuai dengan hasil penelitian Mbanga et al (2014) yang melakuakan penelitian mengenai pengukuran nilai SPF menggunakan spektrofotometri UV menyebutkan bahwa perbedaan signifikan antara nilai SPF yang tertera pada kemasan dengan nilai SPF yang terukur dengan metode spektrofotometri yaitu pada sediaan yang mengandung nilai SPF lebih dari 20. Namun metode spektrofotometri merupakan metode yang sederhana, cepat, dan murah dalam menentukan nilai SPF pada bentuk sediaan lotion maupun krim (Mbanga et al 2014).

Nilai SPF sediaan tabir surya dipengaruhi oleh bahan aktif tabir surya, polaritas pelarut dan $\mathrm{pH}$ sediaan (Soeratri dan Erawati, 2004). Nilai SPF sampel yang tidak dapat terukur dengan metode spektrofotometri berdasarkan penyerapan senyawa tabir surya dari 
larutan dapat disebabkan karena kandungan zat aktif tabir surya berupa titanium dioksida. Hal ini disebabkan karena titanium dioksida tidak memberikan serapan yang cukup besar ketika diukur pada panjang gelombang 290-400 nm. Sehingga metode yang digunakan pada penentuan nilai SPF dengan cara melarutkan sampel dalam pelarut etanol kedalam kuvet kurang cocok untuk bentuk sediaan yang memiliki cara kerja dengan memantulkan sinar UV seperti titanium dioksida, dimana metode penentuan nilai SPF secara in vitro yang lebih tepat untuk sediaan yang mengandung zat aktif titanium dioksida adalah dengan metode pengukuran diffuse transmittance (Setiawan, 2010).

Salvador dan Chisvert (2005) menyebutkan bahwa tidak mudah untuk dapat menganalisis sediaan tabir surya dengan menggunakan metode spektroskopi. Metode tersebut digunakan sebagai pendeteksi setelah dilakukan pemisahan sebelumnya. Hal ini disebabkan karena zat aktif tabir surya berupa UV filter biasanya diformulasi sebagai bentuk sediaan kosmetik, dan hal ini akan sulit jika dilakukan pengukuran secara langsung tanpa pemisahan sebelumnya. Selain itu, komponen matriks juga dapat mempengaruhi hasil analisis. Meskipun metode spektrofotometri bisa digunakan dalam penentuan nilai SPF secara in vitro pada formulasi kosmetik (Dutra et al, 2004).

Uji viskositas dilakukan untuk mengetahui kekentalan sediaan yang mempengaruhi ketika pengaplikasian pada kulit. Hasil pengukuran viskositas sampel terpilih yaitu lotion $\mathrm{P}$ dengan nilai 27.600 cps dan gel $\mathrm{L}$ dengan nilai $28.470 \mathrm{cps}$. Lotion biasanya memiliki viskositas di bawah 50.000 cps (Lowe et al., 1997). Sedangkan viskositas sediaan gel yang baik adalah 20.00040.000 cps (Garg et al., 2002). Dari hasil pengujian viskositas, gel dan lotion menunjukkan nilai viskositas yang memenuhi persyaratan.

\section{Stabilitas Fisik dan Pengukuran Nilai SPF}

Warna yang diamati pada sampel lotion adalah putih sedangkan pada sampel gel adalah putih kebiruan. Warna sediaan gel tidak transparan seperti sediaan gel pada umumnya melainkan putih kebiruan tetapi menurut Formularium Kosmetika Indonesia warna sediaan gel tidak harus transparan (Ditjen POM, 1985).

Pengamatan warna yang dilakukan terhadap masing-masing bentuk sediaan yang disimpan dalam tiga suhu berbeda menunjukkan bahwa semua bentuk sediaan yaitu lotion dan gel yang disimpan tidak mengalami perubahan warna. Hasil ini sesuai dengan penelitian Smaoui et al. (2013) yang menyebutkan bahwa bentuk sediaan emulsi tabir surya yang disimpan pada tiga suhu berbeda tidak mengalami perubahan warna dan stabil selama masa penyimpanan 28 hari.

Pengamatan fisik dilakukan dengan meilhat ada tidaknya pemisahan secara fisik. Sediaan farmasi dinyatakan stabil bila tidak ada perubahan dari kondisi semula (Rosita et al, 2010). Ketidakstabilan fisik dari sediaan emulsi atau krim ditandai dengan adanya pemucatan warna atau munculnya warna, timbul bau, perubahan atau pemisahan fase, pecahnya emulsi, pengendapan suspensi, perubahan konsistensi, pertumbuhan kristal, tebentuknya gas atau perubahan fisik lainnya (Setiawan, 2010). Selain itu, sistem emulsi juga dapat mengalami ketidakstabilan fisik yang bersifat reversibel seperti creaming dan flokulasi atau 
irreversibel seperti koalesen dan inversi fase. Keadaan reversibel masih dapat kembali ke keadaan awal dengan sedikit agitasi, sedangkan irreversibel dapat berakhir dengan pemisahan fase (Eccleston, 2007).

Tabel 2. Data pengamatan warna dan stabilitas fisik dari dua bentuk sediaan tabir surya yang disimpan pada tiga suhu berbeda selama 28 hari

\begin{tabular}{|c|c|c|c|c|c|c|}
\hline \multirow{3}{*}{$\begin{array}{c}\text { Pengamatan } \\
\text { Hari ke- }\end{array}$} & \multicolumn{6}{|c|}{ Kondisi Penyimpanan } \\
\hline & \multicolumn{2}{|c|}{$25^{\circ} \mathrm{C}$} & \multicolumn{2}{|c|}{$4^{\circ} \mathrm{C}$} & \multicolumn{2}{|c|}{$40^{\circ} \mathrm{C}$} \\
\hline & $\mathbf{L}$ & $\mathbf{G}$ & $\mathbf{L}$ & $\mathbf{G}$ & $\mathbf{L}$ & $\mathbf{G}$ \\
\hline \multirow[t]{2}{*}{1} & $\mathrm{P}$ & $\mathrm{PK}$ & $\mathrm{P}$ & $\mathrm{PK}$ & $\mathrm{P}$ & PK \\
\hline & $(-)$ & $(-)$ & $(-)$ & $(-)$ & $(-)$ & $(-)$ \\
\hline \multirow[t]{2}{*}{3} & $\mathrm{P}$ & PK & $\mathrm{P}$ & PK & $\mathrm{P}$ & PK \\
\hline & $(-)$ & $(-)$ & $(-)$ & $(-)$ & $(-)$ & $(-)$ \\
\hline \multirow[t]{2}{*}{7} & $\mathrm{P}$ & PK & $\mathrm{P}$ & PK & $\mathrm{P}$ & PK \\
\hline & $(-)$ & $(-)$ & $(-)$ & $(-)$ & $(-)$ & $(-)$ \\
\hline \multirow[t]{2}{*}{14} & $\mathrm{P}$ & PK & $\mathrm{P}$ & PK & $\mathrm{P}$ & PK \\
\hline & $(-)$ & $(-)$ & $(-)$ & $(-)$ & $(-)$ & $(-)$ \\
\hline \multirow[t]{2}{*}{21} & $\mathrm{P}$ & PK & $\mathrm{P}$ & PK & $\mathrm{P}$ & PK \\
\hline & $(-)$ & $(-)$ & $(-)$ & $(-)$ & $(-)$ & $(-)$ \\
\hline \multirow[t]{2}{*}{28} & $\mathrm{P}$ & PK & $\mathrm{P}$ & PK & $\mathrm{P}$ & PK \\
\hline & $(-)$ & $(-)$ & $(-)$ & $(-)$ & $(-)$ & $(-)$ \\
\hline
\end{tabular}

Keterangan : L (lotion); G (Gel); P (Putih); PK (Putih kebiruan); - (tidak teramati adanya pemisahan fisik sediaan).

Hasil pengamatan fisik yang dilakukan terhadap masing-masing bentuk sediaan yang disimpan dalam tiga suhu berbeda menunjukkan bahwa semua bentuk sediaan yaitu lotion dan gel tidak mengalami pemisahan fisik. Hasil pengamatan ini, sesuai dengan penelitian Smaoui et al. (2013) yang melakukan uji stabilitas sediaan tabir surya yang disimpan pada suhu $8^{\circ} \mathrm{C}$, $25^{\circ} \mathrm{C}$ dan $40^{\circ} \mathrm{C}$ menunjukkan bahwa sediaan stabil dan tidak mengalami perubahan selama masa penyimpanan 28 hari.

Pengukuran nilai $\mathrm{pH}$ sediaan tabir surya (Gambar 1) bertujuan untuk mengetahui derajat keasaman sediaan pada saat digunakan dan untuk memastikan keamanan sediaan agar tidak mengiritasi kulit. Hasil pengukuran $\mathrm{pH}$ pada penelitian ini menunjukkan bahwa bentuk sediaan lotion dan gel yang disimpan selama 28 hari pada tiga suhu berbeda memiliki $\mathrm{pH}$ stabil yaitu 6. Nilai $\mathrm{pH}$ tersebut termasuk pada persyaratan nilai $\mathrm{pH}$ sediaan yaitu 4,5-6,5 (Tranggono, 2007).

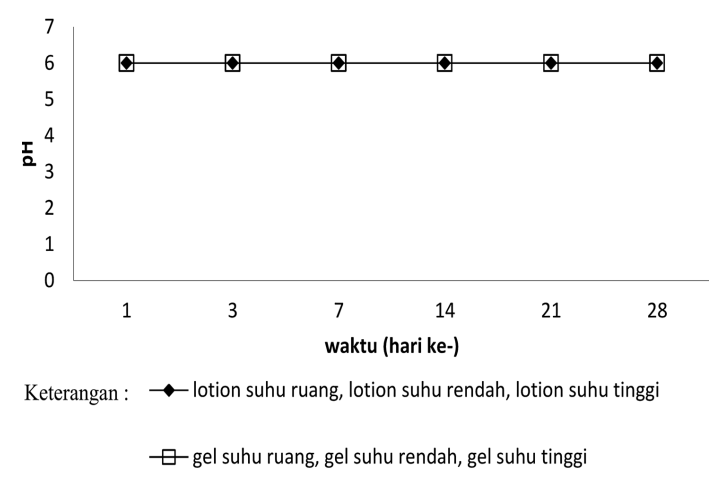

Gambar 1. Nilai pH dari dua bentuk sediaan tabir surya yang disimpan pada tiga suhu berbeda selama 28 hari

Pada penelitian Anggraini et al (2013) yang melakukan pengujian stabilitas sediaan tabir surya menunjukkan bahwa terjadi penurunan pH selama masa penyimpanan namun perubahan tersebut tidak jauh dari rentang $\mathrm{pH}$ kulit dan masih dalam batas yang masih diterima oleh kulit.

Pengujian daya sebar dilakukan untuk mengetahui kemampuan sediaan untuk menyebar pada kulit ketika diaplikasikan. Semakin besar daya menyebar maka sifat fisik sediaan semakin baik (Voigt, 1994). Daya sebar sangat berhubungan dengan viskositas sampel tabir surya. Sampel dengan viskositas kecil akan mempunyai daya sebar yang besar (Pratama dan Zulkarnain, 2015). Daya sebar sediaan yang baik berkisar 5-7 cm (Garg et al, 2002).

Hasil uji daya sebar dari bentuk sediaan tabir surya (Gambar 2) pada penyimpanan suhu ruang $\left(25^{\circ} \mathrm{C}\right)$ menunjukkan bahwa bentuk sediaan gel 
mengalami penurunan diameter daya sebar sementara lotion mengalami peningkatan diameter daya sebar. Sedangkan pada penyimpanan suhu rendah $\left(4^{\circ} \mathrm{C}\right)$, lotion dan gel mengalami peningkatan diameter daya sebar, namun pada penyimpanan suhu tinggi $\left(40^{\circ} \mathrm{C}\right)$ mengalami penurunan diameter daya sebar. Sehingga suhu penyimpanan mempengaruhi daya sebar bentuk sediaan gel.
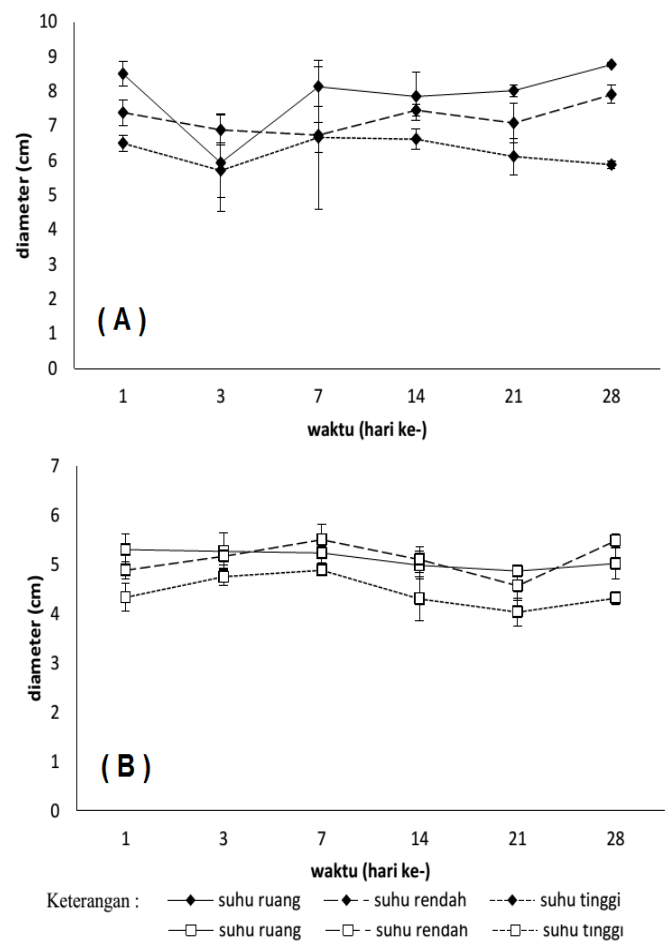

Gambar 2. Daya sebar bentuk sediaan tabir surya (A) lotion da (B) gel yang disimpan pada tiga suhu berbeda selama 28 hari.

Pengukuran daya lekat dilakukan untuk mengetahui kemampuan sediaan melekat pada kulit. Daya lekat sangat dipengaruhi oleh konsistensi dari sampel lotion tabir surya. Suatu sediaan tabir surya diharapkan dapat melekat pada kulit dalam waktu yang lama, sehingga dapat melindungi kulit dari radiasi sinar ultraviolet dalam waktu relatif lebih lama (Pratama dan Zulkarnain, 2015). Hal tersebut akan berhubungan dengan lama waktu kontak sediaan dengan kulit hingga efek terapi yang diinginkan tercapai (Voigt, 1994).
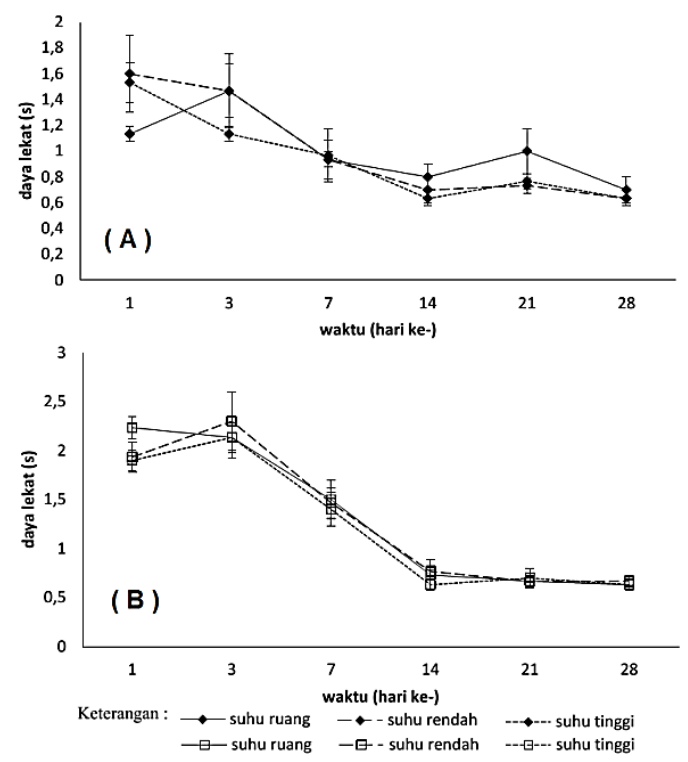

Gambar 3. Daya lekat bentuk sediaan tabir surya (A) lotion dan (B) gel yang disimpan pada tiga suhu berbeda selama 28 hari.

Hasil pengujian daya lekat (Gambar 3) menunjukkan bahwa semua bentuk sediaan yaitu lotion dan gel yang disimpan pada ketiga suhu penyimpanan mengalami penuruan daya lekat, namun cenderung masih memenuhi persyaratan sampai hari ke7. Sedangkan mulai dari hari ke-14 semua bentuk sediaan memiliki daya lekat yang tidak memenuhi persyaratan. Penurunan waktu lekat sediaan menunjukkan bahwa suhu tinggi yang diberikan pada kondisi stress penyimpanan cukup untuk membuat fisik produk berubah yang dipercepat (Bajaj et al., 2012). Menurut Tunjungsari (2012) daya sebar yang semakin rendah maka viskositas dan daya lekat akan semakin tinggi. Sehingga suhu penyimpanan mempengaruhi daya lekat sediaan dan penurunan daya lekat berkaitan 
dengan terjadinya peningkatan daya sebar.

Pengukuran nilai SPF dilakukan dengan mengukur serapan masingmasing sampel menggunakan spektrofotometer UV-Vis (Mbanga, et al, 2014). Hasil pengukuran nilai SPF yang dilakukan terhadap masing-masing bentuk sediaan yang disimpan dalam tiga suhu yang berbeda selama 28 hari (Gambar 4) menunjukkan bahwa semua bentuk sediaan tabir surya yaitu lotion dan gel mengalami peningkatan nilai SPF. Peningkatan yang cukup signifikan terjadi pada bentuk sediaan lotion di hari ke-28 yang disimpan di suhu ruang dan hari ke-14 pada suhu tinggi. Sedangkan bentuk sediaan gel mengalami peningkatan secara signifikan mulai hari ke-14. Penentuan nilai SPF ini penting dilakukan karena SPF menunjukkan efektivitas dari sediaan tabir surya. Hasil yang diperoleh bahwa bentuk sediaan gel menunjukkan stabilitas yang cukup baik pada penyimpanan suhu ruang, rendah, maupun suhu tinggi.

Penelitian Deccache et al (2010) menyebutkan bahwa bentuk sediaan tabir surya berupa gel menunjukkan variasi nilai SPF yang tidak signifikan selama masa penyimpanan dua minggu pada suhu $25^{\circ} \mathrm{C}$ dan suhu $40^{\circ} \mathrm{C}$. Meskipun pada pengamatan nilai SPF yang terukur ada yang mengalami kenaikan dan penurunan. Hal ini disebabkan gel dapat mengalami sineresis. Sineresis adalah peristiwa keluarnya air dari dalam sediaan dimana sediaan mengkerut sehingga cenderung memeras air keluar dari dalam sediaan (Kuncari et al, 2014).
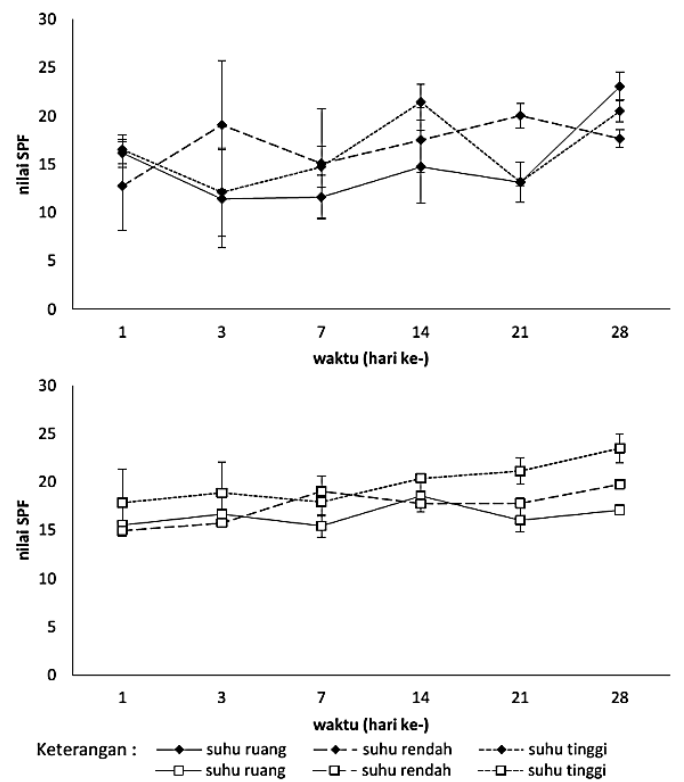

Gambar 4. Nilai SPF bentuk sediaan tabir surya (A) lotion dan (B) gel yang disimpan pada tiga suhu berbeda selama 28 hari.

Sineresis terjadi karena terjadinya struktur matriks atau serat gel yang terus mengeras dan akhirnya mengakibatkan terperasnya air keluar. Hal tersebut dapat menyebabkan viskositas menurun dan menaikan kadar yang terukur (Martin et al, 1993). Sehingga nilai SPF yang terukur menjadi tinggi. Kebalikan dari sineresis adalah diserapnya cairan oleh suatu gel dengan peningkatan volume yang disebut dengan swelling. Peningkatan volume akan menyebabkan viskositas meningkat dan menurunkan kadar (Martin et al, 1993). Sehingga nilai SPF yang terukur menjadi lebih rendah.

Penelitian Rosita et al, (2010) yang melakukan uji stabilitas dan efektifitas sediaan tabir surya menyebutkan bahwa gel mengalami sineresis selama masa penyimpanan 60 hari. Selain itu, penelitian yang dilakukan sebelumnya oleh Smaoui et al. (2013) menyebutkan bahwa bentuk sediaan tabir surya emulsi dengan tiga fotoprotektif benzofenon, etilheksil metoksinamat, dan titanium 
dioksida menunjukkan stabilitas yang baik pada masa penyimpanan 28 hari. Sedangkan pengamatan pada bentuk sediaan lotion hasil yang cukup stabil ditunjukkan pada penyimpanan suhu ruang $\left(25^{\circ} \mathrm{C}\right)$, dan cenderung mengalami kenaikan dan penurunan pada penyimpanan suhu rendah $\left(4^{\circ} \mathrm{C}\right)$ dan suhu tinggi $\left(40^{\circ} \mathrm{C}\right)$.

Nilai SPF yang dihasilkan dari pengujian selama 28 hari secara keseluruhan menunjukkan bahwa masing-masing bentuk sediaan cenderung dapat mempertahankan nilai SPF tabir surya sampai hari ke-7 penyimpanan. Sementara penelitian Smaoui et al. (2013) menyebutkan bahwa bentuk sediaan tabir surya memiliki stabilitas fisik dan kemampuan mempertahankan nilai SPF yang baik selama masa penyimpanan 28 hari. Banyak faktor yang mempengaruhi penentuan nilai SPF seperti penggunaan pelarut tabir surya yang berbeda, kombinasi dan konsentrasi tabir surya, jenisemulsi, efek dan interaksi komponen lain seperti ester, emolien dan pengemulsi yang digunakan dalam formulasi. Beberapa faktor tersebut dapat menyebabkan peningkatan atau penurunan penyerapan UV (Mbanga, et al, 2014).

Hasil analisis ANOVA dari nilai SPF menunjukkan bahwa pada hari ke1 sampai hari ke-7 diperoleh signifikansi lebih dari 0,05 yang berarti bahwa bentuk sediaan baik lotion maupun gel mengalami peningkatan atau penurunan yang tidak signifikan pada ketiga suhu penyimpanan. Sedangkan kedua bentuk sediaan pada penyimpanan suhu rendah dan suhu tinggi setelah penyimpanan hari ke-14 diperoleh nilai signifikansi kurang dari 0,05 yang menunjukkan nilai SPF mengalami perubahan yang signifikan. Sehingga secara keseluruhan bentuk sediaan lotion dan gel dapat mempertahankan nilai SPF sampai hari ke-7 dan mengalami perubahan nilai SPF secara signifikan mulai hari ke-14.

\section{Simpulan}

Kondisi stress penyimpanan yang dilakukan selama 28 hari pada bentuk sediaan tabir surya lotion dan gel mempengaruhi sifat fisik sediaan berupa daya lekat dan daya sebar serta mempengaruhi secara signifikan nilai SPF sediaan $(p<0,05)$ mulai hari ke-14 penyimpanan.

\section{Ucapan Terima Kasih}

Ucapan terima kasih disampaikan kepada Laboratorium Kimia Farmasi dan Laboratorium Farmasetika, Jurusan Farmasi, Fakultas Ilmu Kesehatan Universitas Jenderal Soedirman atas dukungan sarana dan prasarana selama penelitian.

\section{Daftar Pustaka}

Anggraini, T. D., Joshita, D., Hayun, 2013, Uji Stabilitas dan Penentuan Nilai SPF secara In Vitro dari Krim Tabir Surya yang Mengandung Butil Metoksidibenzoilmetan dan Oktil Metoksisisnamat dengan Penambahan Titanium Dioksida, Skripsi, Program Studi Farmasi Fakultas Matematika dan Ilmu Pengetahuan Alam Universitas Indonesia.

Bajaj, S., Dinesh, S., Neha, S., 2012, Stability Testing of Pharmaceutical Products, Journal of Applied Pharmaceutical Science, 02 (03) : 129-138.

Bendova, H., Akrman, J., Krejci, A., Kubac, L., Jirova, D., Kejlova, K., Kolarova, H., Brabec, M., dan Maly, M., 2007, In vitro approaches to evaluation of Sun Protection Factor, Toxicology in vitro, 21 : 1268-1275. 
Deccache, D.S., Elisabete, P.d.S., Lucio, M.C., Carlos, R.R., dan Valeria, P.d.S., 2010, Development of Methodologist for Dimethylaminoethanol glycolate Assay in Association with Sunscreens in Dermocosmetic Formulation, Brazilian Journal of Pharmaceutical Sciences, 46 (4): 705712.

Ditjen Pengawas Obat dan Makanan, 1985, Formularium Kosmetika Indonesia, Departemen Kesehatan Republik Indonesia, Jakarta.

Dutra, E.A., Oliveira, D.A.G., KedorHackmann, E.R.M., Santoro, M.I.R.M.,2004, Determination of Sun Protection Factor (SPF) of Sunscreen by Ultraviolet Spectrophotometry, Brazilian Journal of Pharmaceutical Sciences, 40 (3) : 381-385.

Eccleston, G.M., 2007, Emulsion and Microemulsion in Encyclopedia of Pharmaceutical Technology 3rd edition, Informa Health Care, New York.

Fields, S. W., 2008, Sunscreens: Mechanisms of Action, Use, and Excipients, International Journal of Pharmaceutical Compounding.

Forestier, S., 2008, Rationale for Sunscreen Development, Journal the American Academy of Dermatology, Inc, 58 : S133-8.

Garg, A., Anggarwal, D., Garg, S., dan Sigla, A.K., 2002, Spreading of Semisolid Formulation: An Update, Pharmaceutical technology, 84-102.

Hermann, A., 2004, Guidelines on Stability Testing of Cosmetic Products, The European Cosmetic Toiletry and Parfumery Association, Brussels.

ICH, 2003, Guidance for Industry Q1A(R2) Stability Testing of New Drug Substances and Products, U.S. Department of Health and Human
Services Food and Drug Administration.

Kuncari, E. S., Iskandarsyah, dan Praptiwi, 2014, Evaluasi, Uji Stabilitas dan Sineresis Sediaan Gel yang Mengandung Minoksidil, Apigenin, dan Perasan Herba Seledri (Apium graveolens L), Buletin Peneliti Kesehatan, 42 (4): 213-222.

Lowe, J. N., Nadim, A.S., dan Madhu, A.P., 1997, Sunscreens: Development, Evaluation, and Regulatory Aspects 2nd Edition Revised and Expanded, Marcel Dekker Inc., New York.

Mansur, J.S., Breder M.N.R., Mansur M.C.A., Azulay R.D., 1986, Determination of sun protection factor (SPF) of sunscreens by ultraviolet spectrophotometry, $A n$. Bras. Dermatol, 61 : 121-124.

Martin, A., J. Swarbrick, dan A. Cammarata, 1993, Farmasi Fisika Edisi III, Universitas Indonesia Press, Jakarta.

Mbanga, L., Mulenga, M., Mpina, P.T., Bokolo, K., Mumbwa, M., dan Mvingu, K., 2014, Determination of Sun Protection Factor (SPF) of Some Body Creams and Lotions Marketed in Kinshasa by Ultraviolet, International Journal of Advanced Research in Chemical Science, 1 (8) : 7-13.

Pratama, W. A dan Zulkarnain, A. K., 2015, Uji SPF In Vitro dan Sifat Fisik Beberapa Produk Tabir Surya yang Beredar di Pasaran, Majalah Farmaseutik, 11 (1): 275-283.

Rosita, N., Tutiek P., dan Agustin, 2010, Satbilitas Fisik dan Efektifitas Sediaan Tabir Surya Kombinasi Oksibenson dan Oktil Metoksisinamat dengan Penambahan Asam Glikolat, Majalah Ilmu Kefarmasian, 7 (2): 16-26.

Salvador dan Chisvert, 2005, Sunscreen analysis A critical survey on UV filters determination, Analytica Chimica Acta 537: 1-14. 
Secundinani, H.M., 2016, Formulasi dan Uji Aktivitas Antibakteri Gel Minyak Serai Wangi (Cymbopogon Nardus L.) dengan Basis Carbopol 940 Terhadap Propionibacterium Acnes, Skripsi, Jurusan Farmasi Fakultas Ilmu-Ilmu Kesehatan Universitas Jenderal Soedirman.

Setiawan, Tri, 2010, Uji Stabilitas Fisik dan Penentuan Nilai SPF Krim Tabir Surya yang Mengandung Ekstrak Daun Teh Hijau (Camellia sinensi L.), Oktil Metoksisinamat dan Titanium Dioksida, Skripsi, Farmasi Universitas Indonesia.

Shaath, N. A., 2005, Sunscreen Evaluation. In: Shaath NA, ed. Sunscreens: Regulation and Comercial Development 3rd, Taylor and Francis, Boca Raton-Florida.

Smaoui, S., Hajer, B. H., Ines, B. C., dan Adel, K., 2013, Development and Stability Studies of Sunscreen Cream Formulation Containing Three Photo-Protective Filters, Arabian Journal of Chemistry.

Soeratri, W., Hadinoto, I., dan Anastasia, T., 1993, Penentuan Nilai SPF InVitro Sediaan Krim Tabir Matahari Etilheksil-p-metoksinamat dan Oksibenson, Majalah Airlangga, 1725.

Soeratri W dan Erawati E, 2004, Peningkatan Nilai SPF (Sun Protection Factor) Kombinasi Tabir Surya Oksibenson dan Oktilmetoksisinamat oleh Asam Glikolat, Majalah Farmasi Airlangga, 4 (2).

Tranggono, R. I. S., 2007, Buku Pegangan Ilmu Pengetahuan Kosmetik, Gramedia Pustaka Utama, Jakarta.

Tunjungsari, D., 2012, Formulasi Sediaan Gel Ekstrak Etanolik Buah Mahkota Dewa (Phaleria macrocarpa (Scheff) Boerl.) dengan Basis Carbomer, Skripsi, Fakultas Farmasi
Universitas

Muhammadiyah Surakarta.

Voigt, R., 1994, Buku Pelajaran Teknologi Farmasi Edisi V, Gajah Mada University Press, Yogyakarta. 